\title{
Do stem cell divisions significantly contribute to cancer development?
}

\author{
Ryan Sandarage ${ }^{1 *}$ and Justin G. Chitpin ${ }^{2 \dagger}$
}

\begin{abstract}
Cancer is caused by uncontrolled cellular growth, yet some cancer cells may have greater roles in sustaining tumour proliferation and overcoming conventional cancer treatments. The origins of these cancer stem cells, as they are hypothesized, is widely contested. The current opinion points to extrinsic factors such as smoking, diet and sedentary lifestyle to be the primary inducer of cancer stem cells. This dogma was challenged in 2015 when Tomasetti and Vogelstein postulated that two-thirds of the variation in cancer risk could be explained by random mutations arising during DNA replication in healthy stem cells. Their "bad luck" hypothesis sparked fierce debate and controversy in the scientific community. In this point-counterpoint article, we discuss the random mutation cancer stem cell model and its implications for guiding public health through primary and secondary cancer prevention.
\end{abstract}

Keywords: Cancer; Stem cells; Driver gene mutations; Linear regression

\section{Résumé}

Le cancer est causé par une croissance cellulaire incontrôlée, pourtant certaines cellules cancéreuses peuvent jouer un rôle plus important dans le maintien de la prolifération tumorale et peuvent aider à surmonter les traitements conventionnels contre le cancer. Les origines de ces cellules souches cancéreuses, telles quelles, sont largement contestées. Actuellement, on souligne des facteurs extrinsèques tels que le tabagisme, l'alimentation et le mode de vie sédentaire comme principaux inducteurs des cellules souches cancéreuses. Ce dogme a été contesté en 2015 lorsque Tomasetti et Vogelstein ont postulé que les deux tiers de la variation du risque de cancer pouvaient être expliqués par des mutations aléatoires survenant lors de la réplication de l'ADN dans des cellules souches saines. Leur hypothèse de "malchance " a suscité de vifs débats et controverses dans la communauté scientifique. Dans cet article point-contrepoint, nous discutons du modèle de cellules souches cancéreuses à mutation aléatoire et de ses implications pour guider la santé publique à travers la prévention primaire et secondaire du cancer.

Mots Clés: Cancer; Cellules souches; Mutations génétiques directrices; Régression linéaire

Over the past decade, few articles have stimulated such scientific discourse as the origin of cancer in stem cells. While scientists are stil $l$ working to this day to explain the biological "ground zero" for stem cell cancer, the common belief points to extrinsic factors as be the primary c ause. This paradigm was challenged in 2015 when Tomasetti and Vogelstein published "Variation in cancer risk among tissues can be explained by the nu mber of stem cell divisions" in Science (1). Tomasetti and Vogelstein used mathematical models to demonstrate that cancer risk corre lates more significantly with the number

\footnotetext{
${ }^{*}$ Correspondence: rsand006@uottawa.ca

${ }^{1}$ Department of Cellular and Molecular Medicine, University of Ottawa, 451

Smyth Rd, K1H 8M5, Ottawa, Canada

Full list of author information is available at the end of the article

${ }^{\dagger}$ Equal contributor
}

of stem cell divisions than environmental factors or inherited predispositions. According to their research, twothirds of the variation in cancer risk could be explained by random mutations arising during DNA replication in healthy stem cells (1). Thus, their "bad luck" hypothesis sparked fierce debate and controversy in the scientific community (1-4).

From a deterministic standpoint, cancer discriminates against those who physically harm their bodies. This intuition is best emphasized by th e strong correlation between lung cancer and smokers inhaling carcinogens in cigarette smoke $(5-7)$. While a sedu ctive argument, several confounding pieces of circumstantial evidence led Tomasetti and Vogelstein to re-think this conventional wisdom. If cancer is truly the result of grievous bodily 
harm by external factors, how could cancer rates vary dramatically between different tissues in the body? For in stance, small intestinal cancers are three times less prevalent than brain tumors, yet the brain is exposed to fewer environmental mutagens than the small intestinal epithelium due to the protective blood-brain barrier (1). Furthermore, toxins ingested by individuals move through the gut having unimpeded interactions with intestinal cells. These anomalies led Tomasetti and Vogelstein to seek an alternative explanation for tiss ue-specific cancer risk. They postulated that random mutations in stem cell division may be responsible for causing a significant number of cancers. The more cells divide, the more opportunities there are for mutations to occur in these cells, resulting in unchecked growth and ultimately cancer.

To test this hypothesis, Tomasetti and Vogelstein developed a model to predict how the lifetime stem cell divisions (lscd) in a given tissue affects one's lifetime risk of cancer. For each tissue type, empirical estimates of the total number of stem cells and the number of times they divid ed were used to calculate the lscd. In parallel, the lifetime risks for different cancers were taken from existing literature. Linear regression anal ysis of lscd versus the lifetime risk for different cancers demonstrated that $65 \%$ of the variation in cancer risk could be explained by the number o f stem cell divisions in a healthy individual (1). Roughly one-third of the cancers correlated with extrinsic factors (deterministic tumors), while twothirds correlated with the number of stem cell divisions (replicative tumors) (1). While elegant, Tomasetti and Vogelstein's analysis between cancer risk and cell division is unable to differentiate between the contributions of intrinsic and extrinsic factors citeWu2016. This shortcoming led to Wu et al.'s reply in 2016, which re-interpreted the lscd model, suggesting that extrinsic factors were indeed the dominant cancer-inducing agent (2).

The cornerstone of Wu et al.'s Nature publication, "Substantial contribution of extrinsic risk factors to cancer development" was a thought experiment where an extrinsic mutation is introduced into the environment, increasing the cancer risk by a factor of four (2). Whil e the lscd would change little because mutagens do not actively promote cell division, the lifetime risk of cancer would increase by a factor of four (2). Therefore, Tomasetti and Vogelstein's lscd model and subsequent correlation analysis would yield the same relations, whether or not $\mathrm{m}$ utagens were present. Using mathematical models on real-world data, Wu et al. consistently estimated that extrinsic factors contribute $>70-90 \%$ in most cancers (2). Because of these new findings, Tomasetti and Vogelstein along with $\mathrm{Lu} \mathrm{Li}$ published "Stem cell divisions, somatic $\mathrm{m}$ utations, cancer etiology, and cancer prevention", a follow-up article that clarified their "bad luck" hypothesis, addressing many concerns in their previous article (3).
It is widely accepted that cancer arises from mutations that may be hereditary, induced by environmental exposure, or the result of DNA repli cation errors $(2,8,9)$. Yet, the scientific debate continues between Tomasetti and $\mathrm{Wu}$. Tomasetti et al. have e xtended their analysis to include driver gene mutations classified into three categories: environmental $(\mathrm{E})$, hereditary $(\mathrm{H})$, and replicative (R). In most cancers, three driver gene mutations are required for tumorigenesis to occur (3). Using a similar thought experiment as $\mathrm{Wu}$ et al., where exposure to an environmental mutagen causes a ten-fold increase in cancer, $90 \%$ of cancers would be preventable by simply a voiding exposure to the mutagen (3). However, $40 \%$ of cancers would still be attributed to R-driver gene mutations (3). On the surface, Tomasetti and Vogelstein's result may be surprising, but the concept of a stochastic and unpreventable cancer is $\mathrm{n}$ ot new. Previous research from Cancer Research UK highlighted that exposure to 14 extrinsic factors was attributed to only $42.7 \%$ of cancer in the UK in 2010 (10). This suggests that $57.3 \%$ of cancers could not be attributed to extrinsic factors, echoing Tomasetti and Vogelstein's fin dings.

The scientific community must consider the greater implications of these results on how it guides primary and secondary cancer effort prevent ion. Tomasetti et al.'s classification of deterministic and replicative tumors may better address important public health aspects of cancer prevention. Primary prevention can achieve maximum benefit by focusing on deterministic tumors through preventative measures such as smoking cessatio $\mathrm{n}$ to minimize lung cancer. For replicative tumors, primary prevention efforts are unlikely to be effective; focus should be placed on secondary preve ntion through early-targeted screening. Replicative tumors should not diminish the importance of primary prevention but highlight that not all cancer s can be prevented by avoiding environmental risks. Ultimately, we may never resolve the exact contribution of intrinsic and extrinsic factors to can cer; however, findings from both Tomasetti and $\mathrm{Wu}$ should be channeled towards quantifying cancer-causing constituents and guiding public health throu gh primary and secondary cancer prevention.

\section{Competing interests}

The authors declare that they have no competing interests.

Author details

${ }^{1}$ Department of Cellular and Molecular Medicine, University of Ottawa, 451 Smyth Rd, K1H 8M5, Ottawa, Canada. ${ }^{2}$ Department of Biochemistry, Microbiology and Immunology, University of Ottawa, 451 Smyth Road, K1H 8M5, Ottawa, Canada.

\section{References}

1. C. Tomasetti, B. Vogelstein, Science 347, 78 (2015).

2. S. Wu, S. Powers, W. Zhu, Y. A. Hannun, Nature 529, 43 (2016).

3. C. Tomasetti, L. Li, B. Vogelstein, Science 355, 1330 (2017).

4. C. Tomasetti, et al., Nature 548, E13 (2017). 
5. M. C. Tammemagi, C. D. Berg, T. L. Riley, C. R. Cunningham, K. L.

Taylor, J. Natl. Cancer Inst. 106, dju084 (2014).

6. N. M. Kanodra, G. A. Silvestri, N. T. Tanner, Cancer 121, 1347 (2015).

7. D. M. Burns, Cancer 89, 2506 (2000).

8. O. Fletcher, F. Dudbridge, BMC Med 12, 195 (2014).

9. L. A. McGuinn, et al., Environ. Res. 112, 230 (2012).

10. D. M. Parkin, L. Boyd, L. C. Walker, Br. J. Cancer 105 Suppl 2, 77 (2011). 